\title{
Diretrizes técnicas para locação de limites edificados em praias
}

\author{
Technical guidelines for establishing limits for building on
} the beach



Recebido em 12/01/10 Aceito em 10/10/10

\section{Flávio Campos do Nascimento José Júlio Ferreira Lima}

\section{Resumo}

A locação de limites edificados em praias é importante para projetos de intervenção urbana, por delimitar o domínio privado da vida pública. O muro de contenção tem papel fundamental como limite da área urbanizada, além da função de minimizar os efeitos da erosão e da inundação de áreas ocupadas. Neste artigo são analisados os casos dos projetos de intervenção para a orla da Praia do Amor, na Ilha de Outeiro, que é parte da Região Metropolitana de Belém, e da orla da praia de Marudá, cidade do nordeste do Estado do Pará. A partir de estudos de obras já executadas nessas localidades, foram propostas diretrizes para locação dos limites edificados em praias no que se refere à metodologia de projeto quanto à definição da configuração e locação do paramento, além de referenciais para estudos complementares necessários.

Palavras-chave: Obras de contenção. Muros de arrimo. Paramentos de contenção. Locação e configuração de limites edificados.

\section{Abstract}

Establishing limits for building on beach borders is important in urban intervention projects, since they separate private domain from public life. Contention walls play a crucial role by limiting the area used for building, and also by minimizing the effects of erosion and flooding in urban areas. This article analyzes case studies carried out in Praia do Amor, Outeiro island, in the Metropolitan Region of Belém, and Marudá Beach, a town in the Northeast of the state of Pará, Brazil. Based on the analysis of existing buildings in those locations, this study suggests a set of guidelines for establishing built limits on beaches. This article also provides references for additional studies required.

Keywords: Support walls. Beaches borders. Paraments for contention of beach. Location and configuration of built limits. 


\section{Introdução}

Historicamente, a costa brasileira é ocupada por diferentes configurações espaciais, devido às distintas atividades econômicas ali instaladas, e sujeita a processos morfodinâmicos cujos efeitos afetam a ocupação urbana. As orlas atlânticas e ribeirinhas do Estado do Pará apresentam situações típicas de ocupação antrópica, bem como próprias da diversidade amazônica. A demanda por intervenções urbanas em faixas limítrofes entre a linha d'água e praias é iminente, uma vez que várias cidades têm seu crescimento na direção da água como alternativa econômica. A intensidade da ocupação demanda infraestrutura a ser definida em meio a um ambiente marcado por questões ligadas à conservação ambiental e aos efeitos da dinâmica das águas.

As necessidades de um projeto urbanístico em praias terão naturezas diversas e específicas, quer sejam ligadas ao turismo, lazer e serviços, quer em busca de melhorias para a ocupação residencial. Além disso, esse tipo de projeto precisa atender a questões técnicas, de modo a garantir a manutenção e a estabilidade da obra. O posicionamento do limite entre a área urbanizada e a praia é um dos referenciais importantes para os projetos de urbanização, e os muros de contenção são os elementos físicos que exercem esse papel na maioria dos casos.

Diante da extensão do litoral do Estado do Pará e, consequentemente, do grande número de praias, é fácil observar o significativo número de espaços públicos que necessitam de tratamento urbanístico para melhoria estética e infraestrutural. Muitas orlas apresentam problemas de erosão e inundações que comprometem as edificações, provocando carência nos serviços públicos básicos.

Este trabalho justifica-se pela necessidade de embasamento teórico para fundamentar, sob os pontos de vista técnicos e legais, futuras intervenções urbanas em praias, usando como ponto de partida o posicionamento do limite urbanizado, o muro de contenção, partindo de uma revisão dos padrões de ocupação do solo em áreas costeiras brasileiras e, mais especificamente, da situação amazônica. O ambiente praial é analisado do ponto de vista de sua formação, hidrodinâmica e morfologia, que incidem sobre a questão da locação e configuração dos limites em contato com a linha de água em obras costeiras.

Os estudos de caso que se seguem dão conta de colapsos em função de processos erosivos nas estruturas físicas dos muros de contenção: os casos de Marudá e Outeiro localizados no Estado do
Pará. Por fim, são apresentadas as conclusões e as recomendações deste estudo.

\section{Urbanização da costa brasileira}

Segundo o Projeto Orla (BRASIL, 2004), a ocupação urbana na costa marítima brasileira tem início com a chegada dos europeus em busca de riquezas naturais. Entre as primeiras regiões ocupadas estavam Rio de Janeiro, Salvador e Recife, que apresentavam significativo contingente populacional em suas zonas costeiras até fins do século XIX.

Contudo, esse padrão de ocupação tornou-se problemático a partir da década de 1950, com a intensificação das atividades ligadas ao processo de industrialização, sendo acentuado com a chegada das multinacionais. Nesse período, a urbanização atinge plena expansão, e as cidades crescem vertical e horizontalmente, inclusive em áreas ambientalmente vulneráveis (BRASIL, 2006).

O Brasil deu continuidade aos padrões de ocupação mesmo durante o século XX e manteve o adensamento populacional voltado para o Oceano Atlântico. Nota-se um grande acúmulo de cidades ao longo do litoral nordeste, sudeste e sul, concentrando 12 capitais dos 17 estados litorâneos, em seus $8.698 \mathrm{~km}$ de zona costeira.

Esses núcleos apresentam características peculiares se comparados com outras partes do país:

(a) bases econômicas e mercados de trabalho diversificados;

(b) altos montantes de investimentos públicos e privados;

(c) vários tipos de serviços e oportunidades de consumo;

(d) atividades portuárias e industriais relevantes;

(e) usos turísticos em larga escala; e

(f) desigualdades socioterritoriais acentuadas.

Na Amazônia oriental, a ocupação da orla pelas capitais São Luís e Belém reproduz tais questões. As cidades localizadas em áreas ribeirinhas também apresentam tais desigualdades, fazem com que os benefícios da vida urbana não sejam distribuídos com justiça social.

Assim, as terras urbanas, como produtos de processos sociais geradores de valores econômicos, tornam-se objeto de uma disputa pela terra. Nas grandes cidades, os locais junto às orlas 
são disputados pelo mercado imobiliário, que almeja explorar e usufruir das potencialidades paisagísticas, implantando condomínios, residenciais ou não, de média e alta renda. Nas cidades menores, ocorrem situações semelhantes, porém marcadas por ocupações esporádicas, por se tratar de balneários.

Cabe ressaltar que, assim como nas cidades maiores, a infraestrutura urbana é insuficiente para atender à demanda. A insuficiência nos sistemas de esgotamento sanitário, por exemplo, em grande parte, não atinge os municípios como um todo, prejudicando uma das potencialidades mais importantes: a balneabilidade das praias (BRASIL, 2004).

Em geral, essas áreas possuem situação irregular, seja do ponto de vista ambiental, urbanístico, patrimonial, administrativo e registrário. Essa irregularidade pode gerar conflitos movidos pela diversidade de interesses econômicos.

\section{Processos Morfodinâmicos}

De acordo com Masselink e Short $\left(1993^{1}\right.$ apud FARIAS, 2006, p. 28), a morfodinâmica refere-se à interação entre a atividade dinâmica de alguns processos físicos e as feições morfológicas desenvolvidas por essas atividades, as quais resultam basicamente da arrebentação das ondas.

A morfologia praial relaciona-se com as características dos sedimentos, a dinâmica das ondas, as condições de maré e vento. Durante um longo período, determinada praia tende a exibir um estágio recorrente modal ou mais frequentemente dependente das condições ambientais (ALVES, 2001).

Segundo Muehe (1998), o perfil transversal de uma praia dependerá do ganho ou perda de areia, de acordo com a energia das ondas. Quando houver tempo bom, haverá ganho de sedimento (engordamento), e quando houver tempestade, haverá perda de sedimento (erosão).

$\mathrm{O}$ ciclo de armazenagem e retirada de sedimentos na praia foi caracterizado por Sonu e Van Beek (1971 ${ }^{2}$ apud FARIAS, 2006), que definiram uma sequência típica das configurações dos perfis praiais. Segundo esses autores, a largura da praia, o estoque de sedimentos e a configuração do perfil praial são determinados essencialmente pela

\footnotetext{
${ }^{1}$ MASSELINK, G.; SHORT, A. D. The Effects of the Tide Range on Beach Morphodynamics and Morphology: a conceptual beach model. Journal of Coastal Research, v. 9, n. 3, p. 785-800, 1993.

2 SONU, C. J.; VAN BEEK, J. L. Systematic Beach Changes on the Outer Banks, North Carolina. Journal of Geology, v. 79, p. 416425, 1971.
}

distribuição do excedente do depósito sedimentar na superfície da praia. A configuração convexa está ligada a um perfil mais construtivo, e a concavidade, a um perfil mais erosivo (Figura 1). Esse depósito, denominado de berma, aumenta durante processos de acreção, mas diminui em tamanho e eventualmente desaparece em eventos de erosão (FARIAS, 2006).

Segundo a Escola Australiana de Geomorfologia (SABAINI, 2005), existem seis estágios morfodinâmicos quanto à variabilidade espacial das praias. Esses estágios variam entre dois extremos: o dissipativo e o refletivo.

O estado dissipativo apresenta larga zona de surfe, com baixa declividade e elevado estoque de areia, sendo que a angulação da praia também se apresenta baixa (SABAINI, 2005). Esse estado ocorre em condições de ondas altas e de elevada esbeltez, de ondas de tempestade, ou na presença de sedimentos de granulometria fina (Figura 2).

Já o estado refletivo é caracterizado por elevados gradientes da praia e zona submersa adjacente, o que praticamente elimina a zona de surfe, a berma é elevada e o estoque de areia na zona submersa é baixo (Figura 3) (MUEHE, 1998).

\section{Obras costeiras}

Nos casos em que a orla apresenta algum tipo de problema ambiental ou de infraestrutura, são necessárias intervenções físicas, mesmo de forma provisória, para manter o funcionamento das atividades naturais e antrópicas ali exercidas. Segundo Farinaccio (2008), as obras costeiras podem ter função de proteção, recuperação ou de infraestrutura e lazer.

As obras de proteção têm como objetivo resguardar as edificações erigidas na costa da ação direta das ondas. Podem ser enquadrados os muros de arrimo, as barreiras de rochas, os enrocamentos e molhes. As obras de recuperação são implantadas em áreas que sofrem com recuos e avanços periódicos e têm como meta a reconstrução do ambiente praial mais próximo ao natural. Pode-se citar: engordamento de praia, espigões e gabiões.

Por fim, as obras de infraestrutura e lazer fornecem equipamentos públicos ou privados voltados para o transporte, saneamento, moradia e turismo. As obras de proteção e recuperação normalmente são implantadas para dar suporte a obras dessa categoria. 

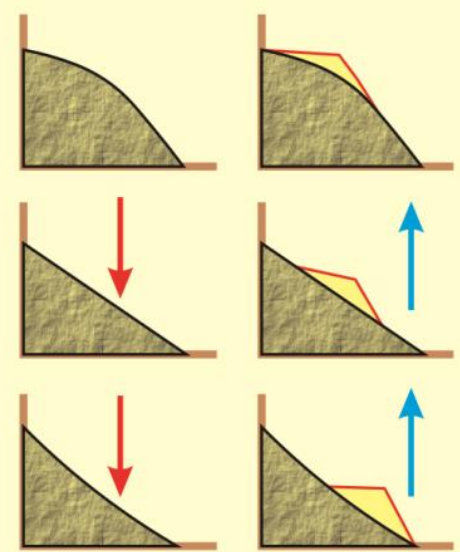

$\longrightarrow$ EROSÃO

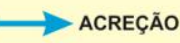

Fonte: adaptação de Sonu e Van Beek ( $1971^{3}$ apud FARIAS, 2006, p. 36)

Figura 1 - Sequência típica de configurações de um perfil de praia com detalhes da concavidade da praia
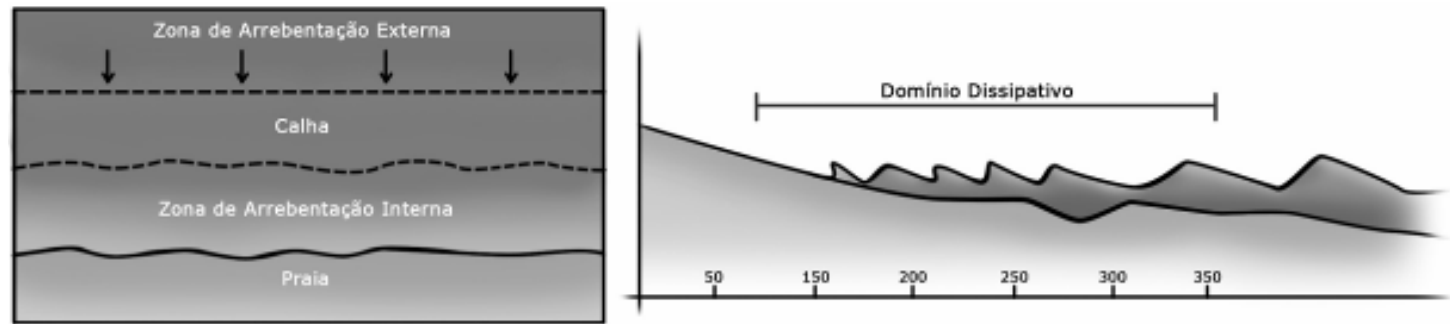

Fonte: adaptado de Wright e Short (1984 apud Sabaini, 2005, p. 29).

Figura 2 - Estado dissipativo
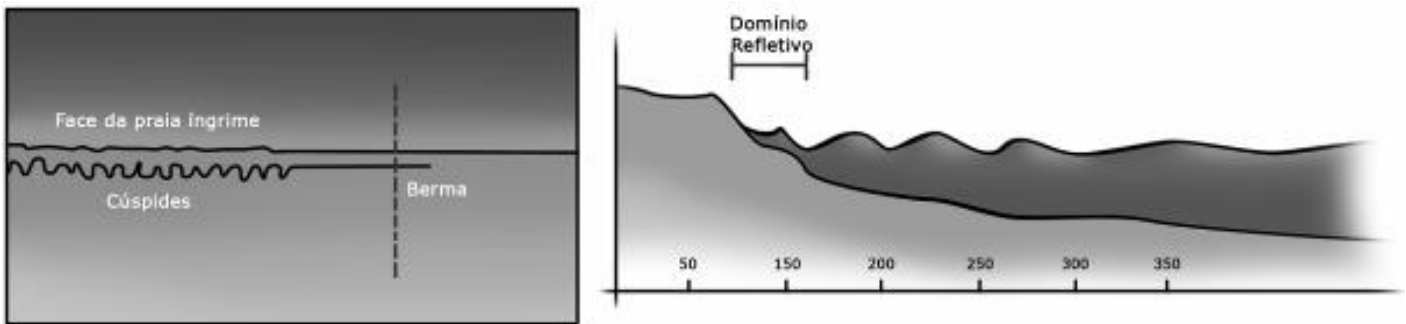

Fonte: adaptado de Wright e Short (1984 apud Sabaini, 2005, p. 29).

Figura 3 - Estado refletivo

\footnotetext{
${ }^{3}$ SONU, C. J.; VAN BEEK, J. L. Systematic Beach Changes on the Outer Banks, North Carolina. Journal of Geology, v. 79, p. 416-425, 1971.

${ }^{4}$ WRIGHT, L. D.; SHORT, A. D. Morphodynamic Variability of Surf zones and Beaches: a synthesis. Marine Geology, v. 56, p. 93-118, 1984.
}

${ }^{5}$ WRIGHT, L. D.; SHORT, A. D. Morphodynamic Variability of Surf zones and Beaches: a synthesis. Marine Geology, v. 56, p. 93-118, 1984. 


\begin{tabular}{|c|l|}
\hline OBRA & \multicolumn{1}{c|}{ POSSÍVEIS IMPACTOS } \\
\hline ESPIGÕES & $\begin{array}{l}\text { Alteração da dinâmica natural longitudinalmente à costa, pelo aprisionamento de sedimentos junto à } \\
\text { estrutura rígida de orientação; surgimento de fenômenos erosivos e escalonamento da linha de costa. }\end{array}$ \\
\hline QUEBRA-MARES & $\begin{array}{l}\text { Acúmulo de sedimentos não desejados. Alteração no transporte litorâneo longitudinal. Instalação de } \\
\text { processos erosivos. }\end{array}$ \\
\hline MUROS MARINHOS & $\begin{array}{l}\text { Alteração da dinâmica natural de transporte de sedimentos pela limitação do espraiamento. Acúmulo de } \\
\text { sedimento e alteração do perfil praial. Colapsos de estruturas e alteração no regime de deposição eólica. }\end{array}$ \\
\hline $\begin{array}{c}\text { ATERROS SOBRE } \\
\text { O PÓS-PRAIA }\end{array}$ & $\begin{array}{l}\text { Alteração na dinâmica natural de transportes de sedimentos pela limitação do espraiamento. Acúmulo de } \\
\text { sedimentos e alteração do perfil praial. Colapsos nas estruturas adjacentes, alteração no regime de } \\
\text { deposição eólica e instalação de processos erosivos. }\end{array}$ \\
\hline EMISSÁRIOS & $\begin{array}{l}\text { Quando expostos influenciam na movimentação longitudinal dos sedimentos ao longo da praia, podendo } \\
\text { iniciar processos erosivos. }\end{array}$ \\
\hline $\begin{array}{c}\text { ENGORDAMENTO } \\
\text { DE PRAIAS }\end{array}$ & $\begin{array}{l}\text { Pode acarretar mudanças significativas na linha da costa, seja pelo aumento excessivo da faixa de praia ou } \\
\text { pela formação de células erosivas. }\end{array}$ \\
\hline
\end{tabular}

Fonte: Farinaccio (2008, p. 23).

Quadro 1 - Exemplos de obras costeiras e seus impactos na dinâmica costeira

Farinaccio (2008) afirma que obras costeiras como quebra-mares, espigões, engordamentos de praia, emissários, muros marinhos, dragagens de canais e da face praial, barragens, etc., podem "alterar a linha de costa ou mesmo interferir na dinâmica costeira, acarretando impactos pontuais ou mesmo reflexos regionais" (Quadro 1).

Precisa-se enfatizar que, em qualquer intervenção costeira, é necessário considerar a dinâmica marinha e principalmente as alterações, no ambiente, provocadas pelas próprias obras, para que não haja o comprometimento acelerado da vida útil da obra (FARINACCIO, 2008).

\section{Obras de proteção e recuperação da costa}

Essas obras têm o objetivo de resguardar as propriedades, privadas ou públicas, contra as ações diretas da maré. Nos casos necessários, as obras recompõem o perfil praial para garantir o desenvolvimento das atividades ali exercidas (FISCHER, 2005). Medidas mitigadoras de erosões e inundações podem ser tomadas para estabelecer o equilíbrio praial: executar estruturas rígidas para dissipar a ação da maré; estabelecer o recuo de proteção das construções às margens dos rios e marés; e fazer o engordamento artificial das praias para garantir o aumento da área útil da praia e garantir a utilização pela população (NORDSTROM, $1992^{6}$ apud FISCHER, 2005).

Fischer (2005) classifica as ações de estabilização entre ações de relocação e desapropriação, leves e pesadas. As ações de desapropriação identificam as áreas de risco, relocam e indenizam, em alguns casos, os donos dos imóveis, tirando-os das áreas em situação de erosão. As medidas leves são as que não necessitam de obras complexas de

${ }^{6}$ NORDSTRON, K. F. Estuarine Beaches: an introduction to the physical and human factors affecting use and management of beaches in estuaries, lagoons, bays and fjords. New York: Elsevier Science Publishers, 1992. 225 p. engenharia. E, por fim, as pesadas são as obras de engenharia costeira que empregam materiais pesados como o concreto, madeiras, rochas, etc.

Porém, avaliações quanto aos impactos causados pelas próprias obras são pertinentes e devem ser feitas visando evitar problemas como os colapsos das estruturas e consequências nocivas ao perfil praial.

Farinaccio (2008) exemplificou os principais impactos das obras sobre as praias arenosas:

(a) redução da faixa de praia;

(b) aumento da extensão das praias;

(c) alteração da topografia da praia, o perfil praial; e

(d) instalação de processo erosivo.

As estruturas de contenção, também chamadas de muros de arrimo ou muros de peso, podem ser construídas em alvenaria (tijolos ou pedras) ou em concreto (armado ou simples) (UNIVERSIDADE..., 2009). Os muros são os elementos mais comuns e presentes nas orlas do Estado do Pará por apresentarem boa funcionalidade e domínio da tecnologia e execução das estruturas.

\section{Principais tipos de muros de contenção}

Os muros de contenção podem ser de gravidade e de flexão, com ou sem contraforte, e com ou sem tirantes (UNIVRSIDADE..., 2009). Os muros de gravidade, ou muros de peso, podem ser classificados de acordo com seus materiais e técnicas construtivas. Segundo Cativo (2009), os tipos de muro de peso mais encontrados em orlas do Estado do Pará são:

(a) alvenaria de pedra: as pedras são arrumadas manualmente, não se utiliza argamassa em sua composição, e sua resistência depende da forma como as pedras são dispostas (Figuras 4 e 5). É 
recomendada apenas para desníveis de até 2 metros, a base do muro deve ter largura mínima de $0,5 \mathrm{~m}$ a $1,0 \mathrm{~m}$, e deve ser apoiada em uma cota inferior à da superfície do terreno, de modo a reduzir o risco de ruptura por deslizamento no contato muro-fundação;

(b) concreto ciclópico ou concreto massa: é recomendado para alturas de até $4 \mathrm{~m}$. Sua execução consiste no preenchimento de formas por concreto e blocos de rochas de tamanhos variados; apresentam, normalmente, secção trapezoidal, tendo sua base $50 \%$ de sua altura. É indispensável um sistema adequado de drenagem nesse tipo de estrutura, conforme se verifica nas Figuras 6 e 7;

(c) muro de gabião: é um cesto de aço galvanizado, preenchido por pedras arrumadas manualmente. Suas principais vantagens são a flexibilidade, a resistência a recalques do terreno e a permeabilidade da estrutura (Figuras 8 e 9). Porém, dificulta o acesso à praia e, uma vez destruída sua tela, torna-se difícil manter a arrumação das pedras em seu interior (SOUZA, 2008); e

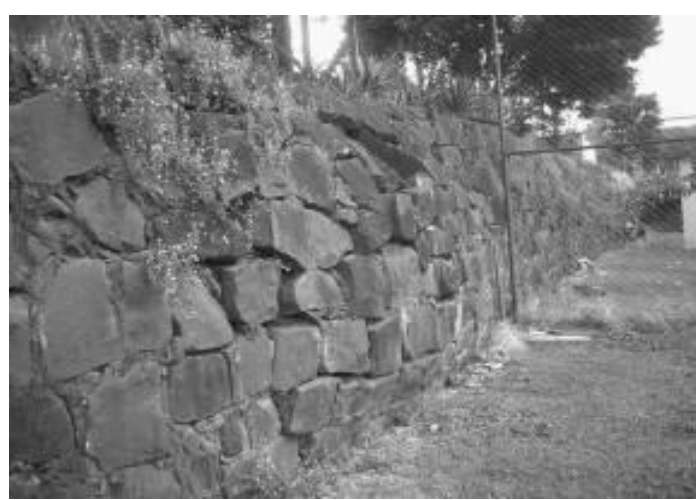

Figura 4 - Muro de pedras

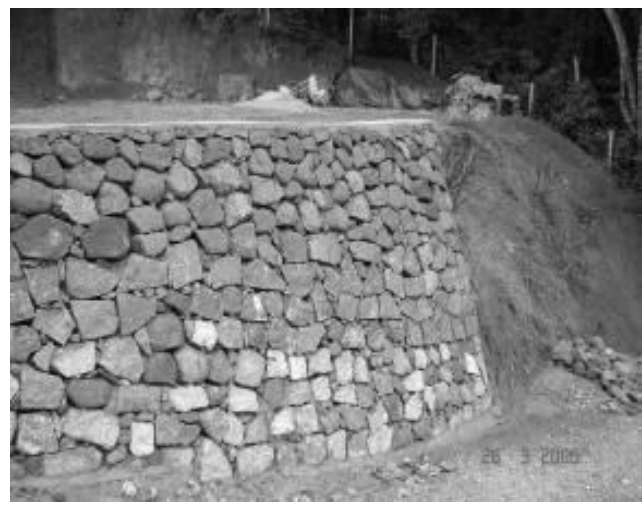

Figura 5 - Muro de pedras

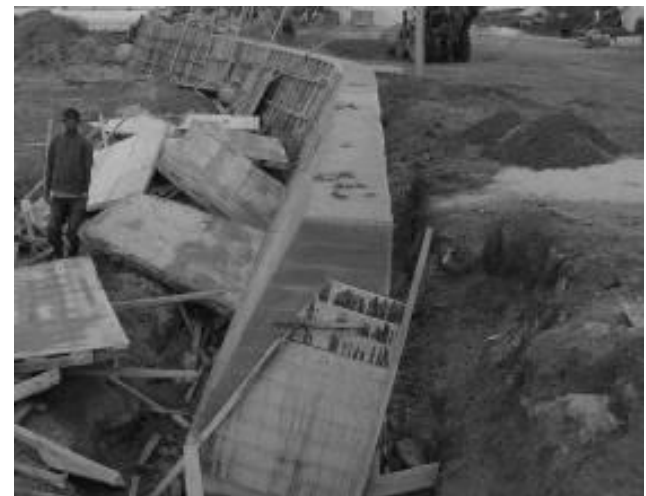

Figura 6 - Muro de concreto ciclópico, Marudá (PA) em julho de 2004 


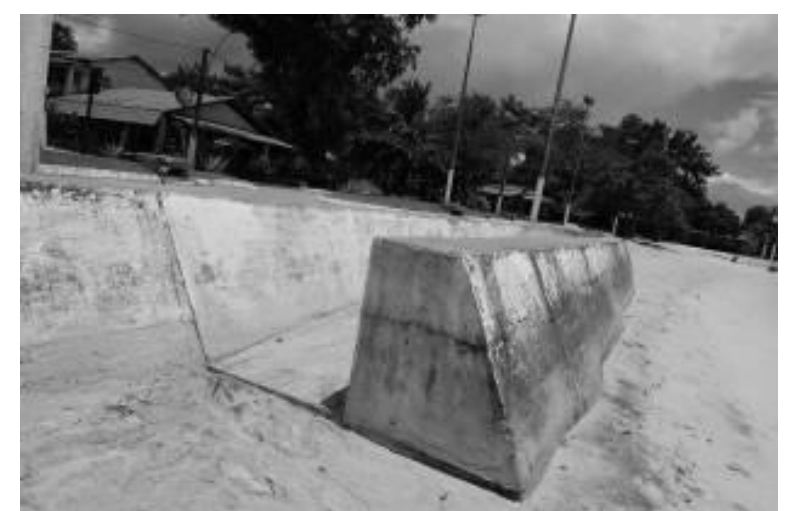

Figura 7 - Muro de concreto ciclópico, Outeiro (PA) em maio de 2009

Figura 8 - Muro de gabião
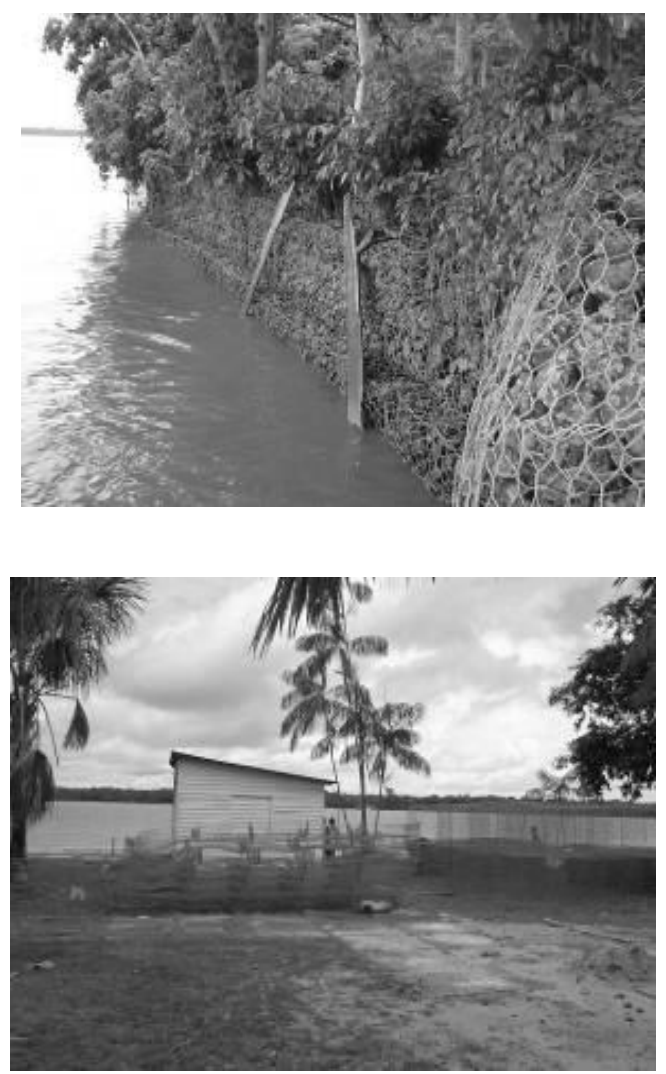

Figura 9 - Cestos metálicos para arrumação das pedras

(d) sacos de solo-cimento: são sacos de poliéster, preenchidos com a mistura de cimento-solo na proporção 1:10 a 1:15. São dispostos empilhados horizontalmente, de forma propositalmente desencontrada da camada imediatamente inferior, para melhor compactação. É possível executá-lo em formas curvas, acompanhando a linha da costa e a topografia do terreno, e não necessita de mão de obra nem equipamentos especializados. Porém, segundo Cativo (2009) ${ }^{7}$, em nossa região, não apresenta um custo mais atrativo que os demais tipos de muro de peso (Figuras 10 e 11).

${ }^{7}$ Informação verbal em entrevista concedida em 10 de março de 2009, por Edenilton Pantoja Cativo.

\section{0 processo erosivo e o estabelecimento de limites de proteção da orla}

A dinâmica da faixa costeira está submetida tanto a processos naturais como antrópicos, que potencializam os efeitos da erosão. Limites de proteção, ou mesmo a proibição do uso de partes dessas áreas, estão sendo estabelecidos como forma de manter as características paisagísticas e de prevenir as perdas materiais por meio da erosão costeira. 
Foto: Freitas (2009).

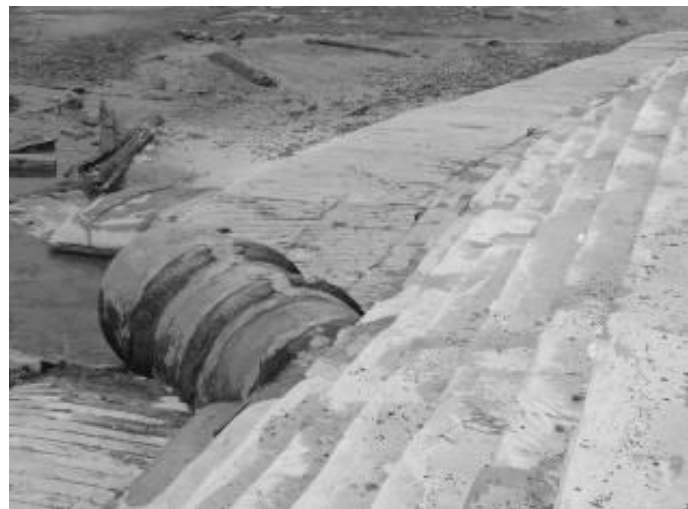

Figura 10 - Muro em sacos de solo-cimento

Figura 11 - Contenção em sacos de solo-cimento



Segundo Muehe (2004), pode-se estabelecer limites do perfil ativo da orla, levando em conta critérios hidrodinâmicos - exposição ou não da praia às ondas de tempestade - e morfodinâmicos - caracterizados pela variabilidade topográfica do fundo marinho associada ao movimento de ondas.

Limites legais também foram estabelecidos para fins de gerenciamento (MUEHE, 2004). O limite de $33 \mathrm{~m}$ a partir da linha de preamar de 1831, estabelecido pelo Decreto-lei 9.760/46, além de difícil delimitação, com frequência não ultrapassa os limites da berma de praias mais largas. A elevação do nível do mar ao longo do tempo também deve ser considerada na definição dos limites terrestres. Portanto, para a definição dos limites terrestres deverão ser considerados dois aspectos: o alcance do processo morfodinâmico atual; e o efeito da elevação do nível do mar.

No primeiro caso, o limite dinâmico da parte emersa será o do alcance máximo do processo deposicional de sedimentos provenientes da praia. Logo, será a porção mais interiorizada da berma mais elevada ou, no caso de cordões litorâneos submetidos à transposição por ondas (overwash), o limite do reverso desse cordão. No caso em que predomina o transporte eólico, o limite será a base do flanco reverso do campo de dunas frontais (MUEHE, 2004).

Os efeitos de uma elevação do nível do mar sobre diferentes tipologias costeiras também devem ser levados em consideração e estão apresentados no Figura 12

A situação A é representada no Brasil pelas falésias do Grupo Barreiras, encontradas em grande parte do litoral intertropical, sendo a resposta a um recuo da linha costeira. O exemplo $\mathrm{B}$ corresponde às planícies costeiras dos Rios Jequitinhonha e São Francisco, por exemplo, demonstrando a erosão da linha costeira e a redução da largura da planície. 
Evouf to DIRANTE ETA: UzACto HO HOĹC.No
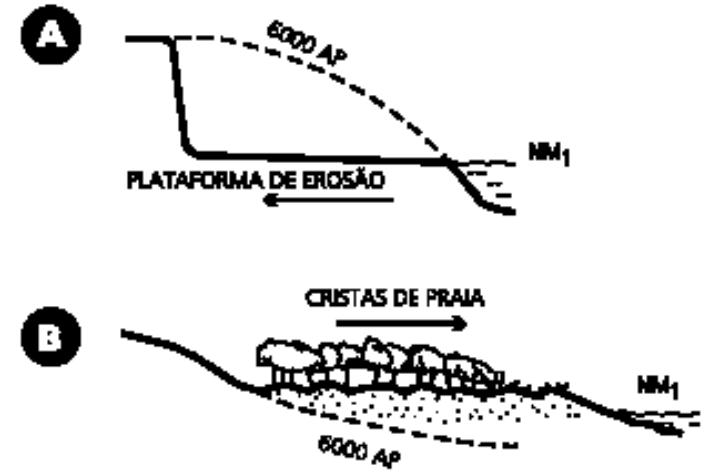

$\boldsymbol{c}$
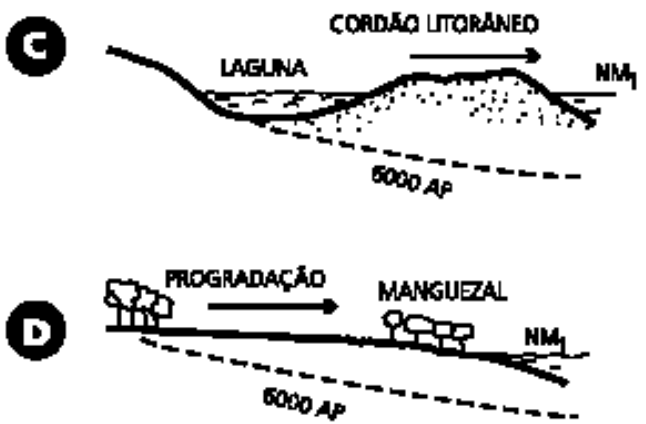

\section{RESPOSTA A UMA RARD}

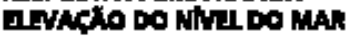
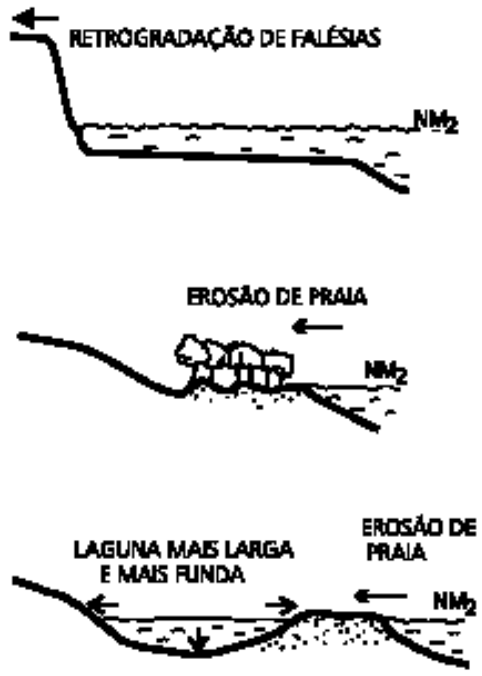

RETROCRADACKO

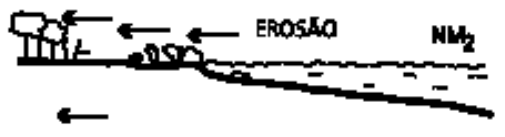

Fonte: Bird $1987^{8}$ apud Muehe, 2004, p. 17.

Figura 12 - Resposta geomorfológica de diferentes tipos de costa a uma elevação do nível do mar

A Figura 12c representa um cordão litorâneo ou pontal. No caso em que se formem lagunas nas retaguardas dos cordões litorâneos, ocorre o alargamento e o aumento da profundidade delas. Quando os cordões e pontais são largos, ocorre erosão na face oceânica, instalando-se o processo de migração apenas quando a largura e a altura permitirem a ultrapassagem das ondas. A situação D ilustra a erosão e a inundação, após a elevação do nível do mar, sobre um manguezal. A erosão poderá ser parcialmente compensada por meio de migração de sedimentos para as áreas inundadas do entorno.

Acerca da distância entre a linha da costa e as profundidades de fechamento do perfil da costa brasileira, Muehe (2004) constatou que a maior parte da plataforma continental apresenta declividades muito baixas (inferiores a $0,2^{\circ} \mathrm{em}$ média). Essas declividades influenciam fortemente nos efeitos de erosão e inundação, conforme exemplificados nas figuras acima; consequentemente, o processo de retrogradação da linha da costa atinge centenas de metros em declividades mais baixas.
Portanto, é necessário que se observem as características locais com relação às tendências evolutivas do litoral para se estabelecer a zona de proteção da orla. Para isso, tanto a escala de tempo geomorfológica (centenas de milhares de anos) quanto a escala de tempo atual (anos e décadas) devem ser consideradas.

A definição da largura da faixa de proteção é um processo variável no tempo, devendo ser modificável e se fundamentar na aquisição de conhecimento por meio de pesquisas geológicas, geomorfológicas e oceanográficas, acrescidas de monitoramento topográfico contínuo de pontos criteriosamente selecionados do litoral.

Segundo Muehe (2004), várias nações estabelecem seus limites de proteção de acordo com suas necessidades específicas. Na Turquia, a orla está dividida em faixas, onde são estabelecidos $50 \mathrm{~m} \mathrm{a}$ partir da linha da praia sem nenhum tipo de construção e mais $50 \mathrm{~m}$ apenas destinados à circulação e obras de infraestrutura, somando 100 $\mathrm{m}$ ou mais de faixa de segurança (Figura 13).

${ }^{8}$ BIRD, E. Physiographic Indications of a Rising Sea Level.

Melbourne: Department of Geography, University of Melbourne, 1987. 
Conforme demonstrado na Figura 13, na Zona A, excetuando-se as obras que possam ser executadas conforme o descrito para a faixa de praia, não poderão ser erguidas quaisquer outras construções. A faixa destina-se exclusivamente a pedestres e recreação. Já a Zona B, que compreende o restante da faixa litorânea, tendo largura de pelo menos 50 $\mathrm{m}$, poderia conter estradas, além de instalações destinadas à recreação e turismo para uso público. Instalações públicas para tratamento de esgoto poderão ser construídas nessa faixa, desde que autorizadas (MUEHE, 2004, p. 25).

Ainda conforme Muehe (2004), o exemplo do estado norte-americano da Carolina do Norte leva em consideração a taxa de erosão costeira. Determina que construções de estruturas leves sejam erigidas a uma distância de trinta vezes a taxa de erosão (m/ano), medida a partir da primeira linha de vegetação natural estável, ou da base do reverso da duna frontal ou da crista da duna primária (Figura 14).
Para construções pesadas (prédios altos), pode-se construir a uma distância de sessenta vezes a taxa de erosão, também medida a partir da primeira linha de vegetação natural estável, ou trinta vezes a taxa de erosão acrescida de $32 \mathrm{~m}$ (Figura 15).

Segundo Muehe (2004), considerando o aumento do nível da água e os processos de erosão e inundação, é pertinente a discussão acerca do estabelecimento dos limites de proteção para as orlas, especialmente em decorrência das ocupações inadequadas na zona costeira brasileira.

A proposta para a faixa mínima de proteção costeira para o Brasil, segundo Muehe (2004), seria de $100 \mathrm{~m}$. Contudo, sabe-se que essa medida sofreria muitas resistências, não apenas por parte do sistema imobiliário, mas também pelas edificações já erguidas em orlas com urbanização consolidada e que dificilmente serão removidas. Portanto, seria razoável estabelecer o limite mínimo de proteção em $50 \mathrm{~m}$ para áreas com urbanização consolidada e de $100 \mathrm{~m}$ para áreas não ocupadas.

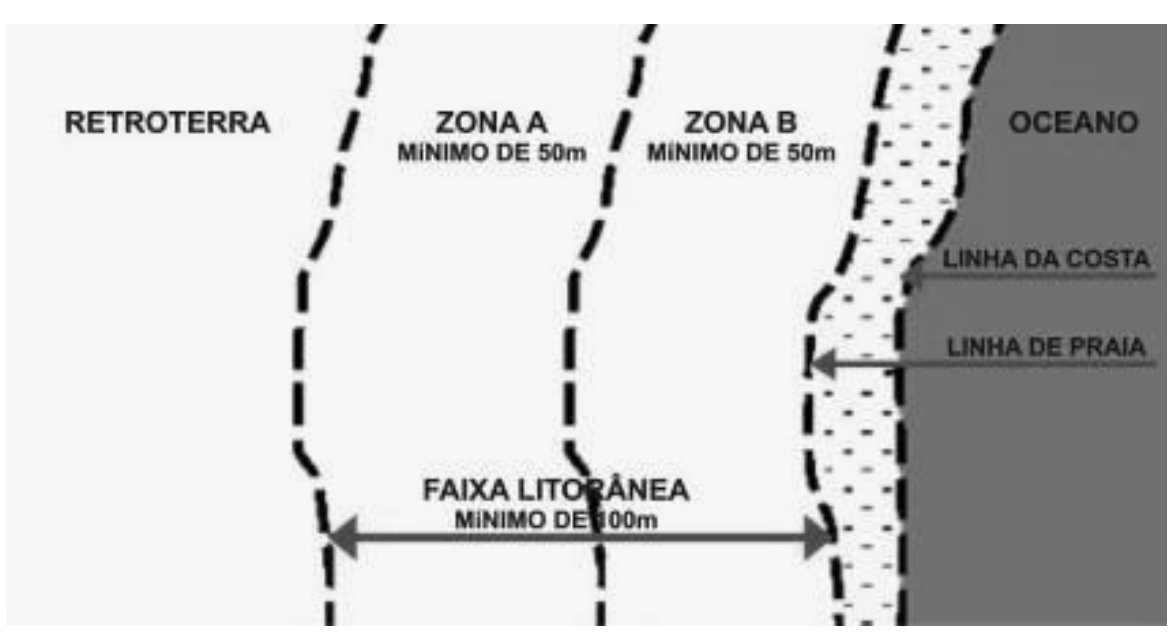

Fonte: adaptada de Cicin-Sain e Knecht (1998).

Figura 13 - Definição de faixas de zoneamento costeiro na Turquia 

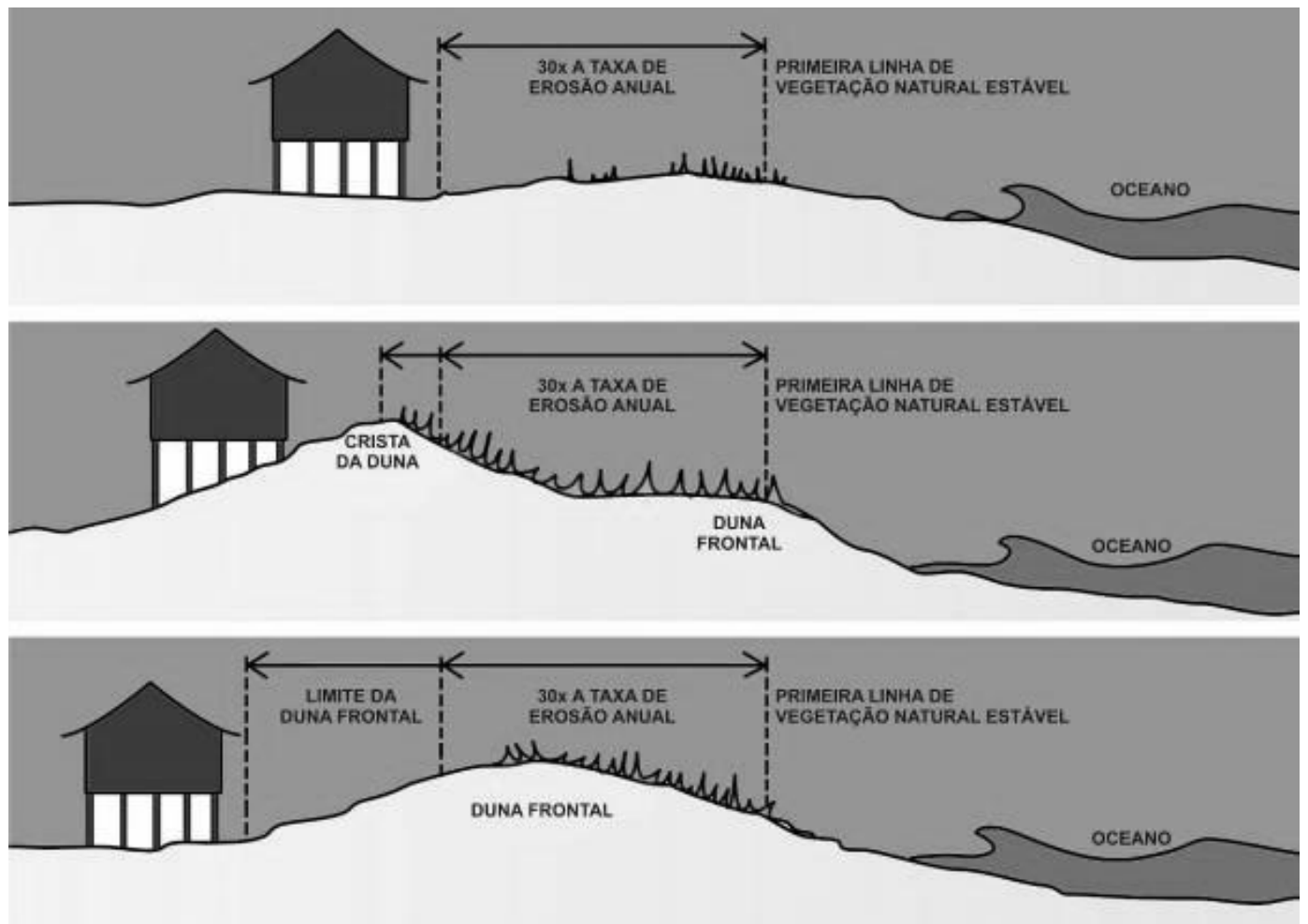

Fonte: adaptado de Cicin-Sain e Knecht (1998).

Figura 14 - Recuos mínimos para construções de estruturas leves na orla da Carolina do Norte (EUA) adotados a partir de 1979

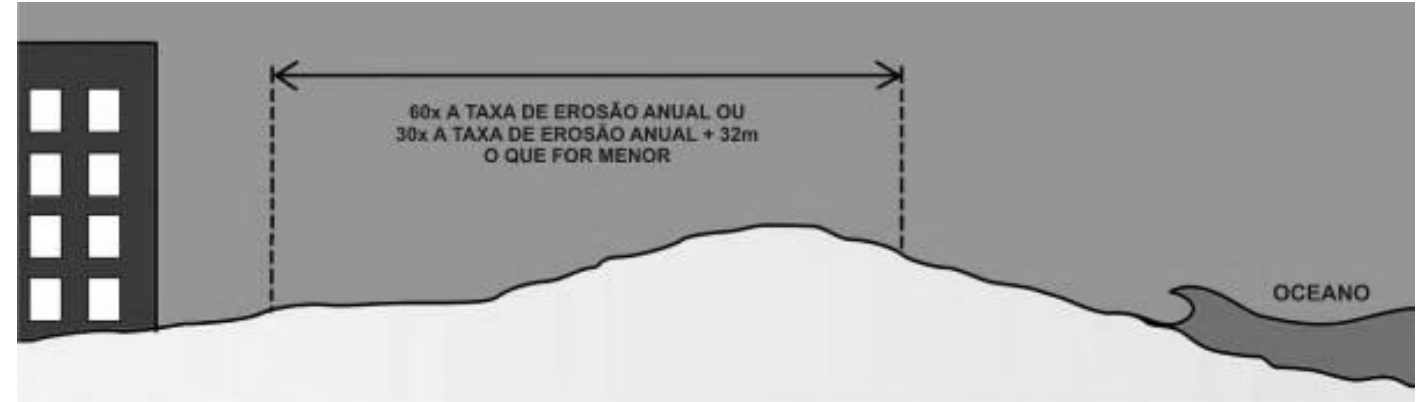

Fonte: adaptado de Cicin-Sain e Knecht (1998).

Figura 15 - Recuos mínimos para construções de estruturas pesadas na orla da Carolina do Norte (EUA) adotadas a partir de 1979

Assim, nas áreas de maior ocupação, a fixação de uma faixa mínima de $50 \mathrm{~m}$, contada a partir do limite terrestre mais interiorizado do prisma praial emerso, já representaria um avanço significativo nesse sentido. Exemplo disso observa-se em parte da orla da Barra de São João, no Estado do Rio de Janeiro, onde uma faixa um pouco menor que $50 \mathrm{~m}$ foi deixada livre de construções, permitindo ampla visão para o mar, além de constituir um espaço para instalação de quadras de esporte, arborização e outras obras paisagísticas (Figura 16) (MUEHE, 2004, p. 27).
Relembra-se que as especificidades de cada região devem ser observadas, além de ser recomendado que se observe o comportamento erosivo do perfil.

\section{Colapsos nas estruturas físicas dos muros de contenção: os casos de marudá e outeiro}

Após constatar que variáveis antrópicas e naturais influenciam na morfologia praial, pode-se afirmar que o movimento de marés e o tipo de obra realizada nas orlas podem alterar positiva ou negativamente o perfil da praia. Segundo Cativo 
(2009), os muros de peso são as estruturas físicas mais usuais para auxiliar no combate à erosão e inundações no Pará, além de desempenharem a função de limite físico entre a parte urbanizada e a praia. Por serem estruturas mais suscetíveis à ação da maré, essas estruturas necessitam de cuidados quanto a sua locação e ao método construtivo no momento do planejamento da obra.

Para demonstrar a importância do posicionamento do muro de contenção para a orla, apresentam-se análises de dois casos no Estado do Pará. O primeiro é o do muro da praia atlântica de Marudá, município de Marapanim, obra de 2004, e o segundo, uma intervenção em ambiente ribeirinho, a Praia do Amor, em Outeiro, na Região Metropolitana de Belém (RMB), muro construído em 2005.

\section{Intervenção na praia de Marudá}

Marudá é uma localidade balneária pertencente ao município de Marapanim, nordeste do Estado do Pará. Situada de frente à Baía de Marudá, foz do Rio Marapanim, a cidade possui $1.600 \mathrm{~m}$ de praia de água salgada. Além de sua beleza natural, o facilitado acesso rodoviário $(14,4 \mathrm{~km}$ da sede do município; e $160 \mathrm{~km}$ da capital do Estado) e a boa infraestrutura de apoio à população (sistema de abastecimento de água, energia elétrica e telefonia fixa e celular de diversas concessionárias) são os principais fatores que fazem com que a localidade seja uma das mais visitadas do Estado.

Nos últimos anos, o fluxo crescente da atividade turística demandou a necessidade de incrementação da infraestrutura instalada, não apenas para contemplar a numerosa população flutuante, mas, também, para disciplinar o parcelamento e o uso do solo da localidade. Atualmente, a praia de Marudá está em processo de ocupação, com estabelecimento de diversos lotes seguindo uma linha sinuosa, com suas frentes voltadas para a areia, por onde se processam seus acessos. Por meio de análise visual, nota-se que as edificações à beira da praia estão posicionadas sobre a berma praial ou mesmo sobre as dunas frontais, o que não é recomendado sob o ponto de vista da preservação do perfil topográfico da praia (Figuras 17 e 18).

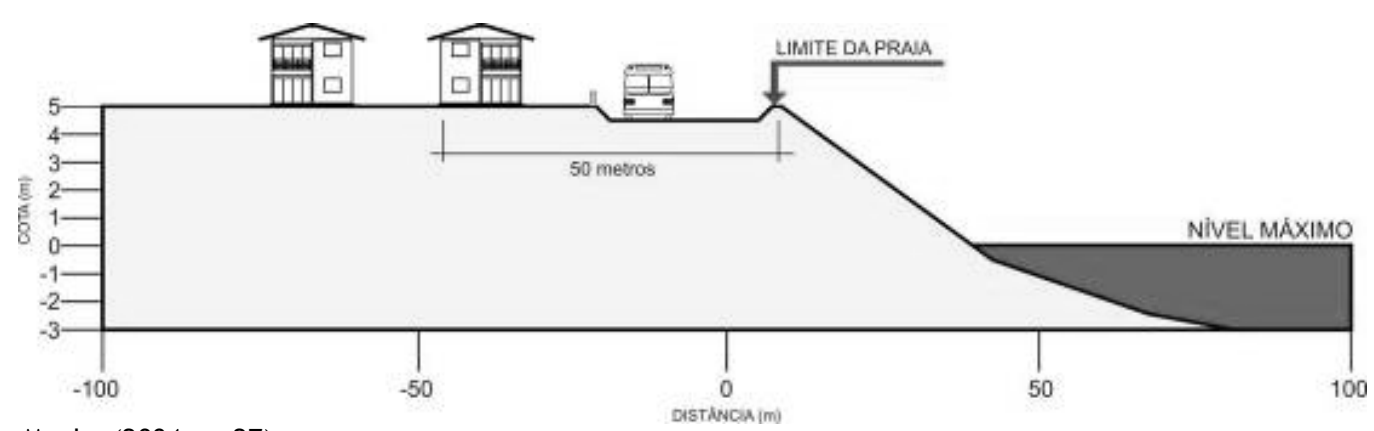

Fonte: Muehe (2004, p. 27).

Figura 16 - Exemplo de uma faixa de proteção de aproximadamente $50 \mathrm{~m}$ de largura, medida a partir do limite interno da berma em contato com a planície costeira (apesar da existência de uma faixa relativamente larga não edificada, as primeiras casas ainda estão aquém do limite de $50 \mathrm{~m}$ )

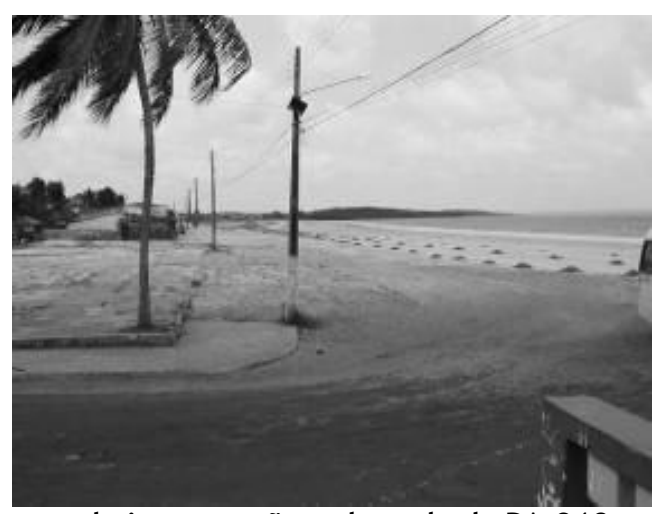

Figura 17 - Situação da praia antes da intervenção - chegada da PA-318 em Marudá, novembro de 2003 


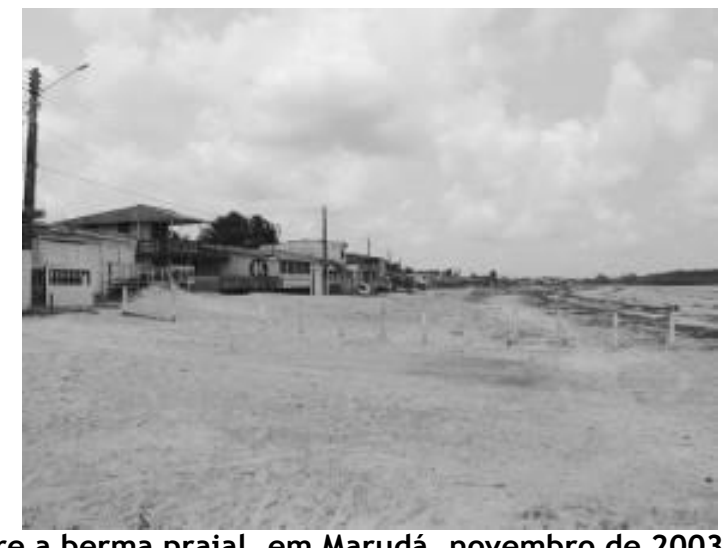

Figura 18 - Edificações sobre a berma praial, em Marudá, novembro de 2003

Em períodos de férias e feriados, a praia é palco de eventos diversos, como, por exemplo, shows e feiras, instalando-se, para isso, uma infraestrutura provisória de atendimento à população. Diante do quadro geral apresentado, o Governo do Estado do Pará construiu uma via litorânea ao longo de parte da orla e, também, uma praça para grandes eventos (Figura 19).

A via litorânea inicia-se ao final da Rodovia PA318 e desenvolve-se ao longo de aproximadamente $500 \mathrm{~m}$ pela orla, até encontrar a via paralela à referida rodovia. A nova via possui 78 vagas de estacionamento e calçadão com larguras que variam entre $4 \mathrm{~m}$ e $10 \mathrm{~m}$, no qual estão dispostos bancos em toda a sua extensão, além de abrigos, em pontos de convivência, nas porções mais largas. As pistas de rolamento foram asfaltadas, e as calçadas são em piso cimentado (Figura 20).

Para realizar a contenção do aterro necessário para todo o sistema de via e calçadas, foi construído um muro de contenção em concreto ciclópico de perfil trapezoidal. Os acessos à praia são realizados por dois conjuntos de rampas para pedestres, posicionados ao longo do calçadão, e também por duas rampas contíguas às vias para descida de veículos à praia. Durante o período de execução da obra, no local da rampa de descida à praia localizada ao fim da PA-318, decidiu-se executar uma rampa de pedestres semelhante às outras, permanecendo, portanto, apenas um acesso de veículos à praia.
Quanto ao muro de contenção do aterro do sistema viário, foi posicionado de forma paralela à linha das fachadas das edificações. Seu paramento apresenta secção trapezoidal, executado em concreto ciclópico. Esse tipo de solução, além de ser adequado estruturalmente à situação em questão, também é econômico, já que permite fácil execução e utiliza materiais existentes de forma abundante em nossa região (CATIVO, 2009)(Informação verbal) ${ }^{9}$.

A secção típica apresenta a metragem de 20,20 m de perfil do sistema viário, se medida a partir da linha do passeio mais próxima aos lotes até a base do muro de contenção. Observa-se no desenho que o muro, em grande parte de sua extensão, mantém certa distância da linha de maré alta, resguardando, com certa segurança, a integridade da estrutura (Figura 21)

Porém, durante a execução da obra, constatou-se um deslocamento na locação do eixo do sistema viário e, consequentemente, o muro de arrimo e as rampas se projetaram $8 \mathrm{~m}$ sobre a água, aproximadamente. Assim, duas das rampas de acesso à praia (Nova Rampa e a Rampa 1) apresentaram uma proximidade indesejada com relação à ação da maré, o que comprometeu a funcionalidade e a estabilidade da estrutura (Figura 22).

${ }^{9}$ Informação verbal em entrevista concedida em 10 de março de 2009, por Edenilton Pantoja Cativo. 


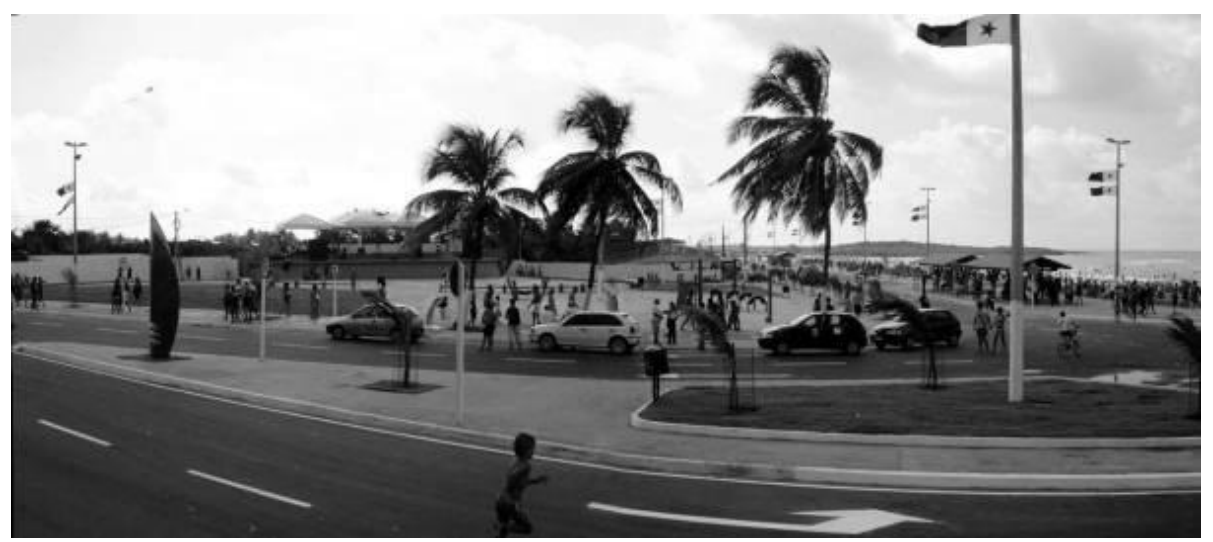

Figura 19 - Vista geral da praça de eventos - palco ao fundo, Marudá, julho de 2004

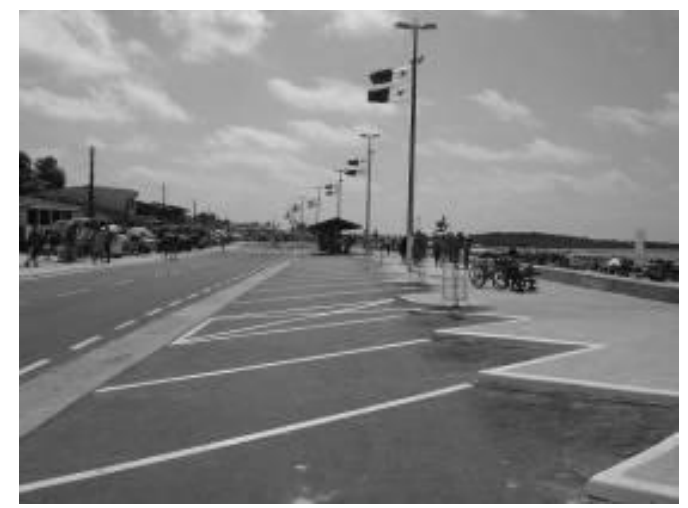

Figura 20 - Perfil do sistema viário. Lotes e edificações à esquerda, em Marudá, julho de 2004

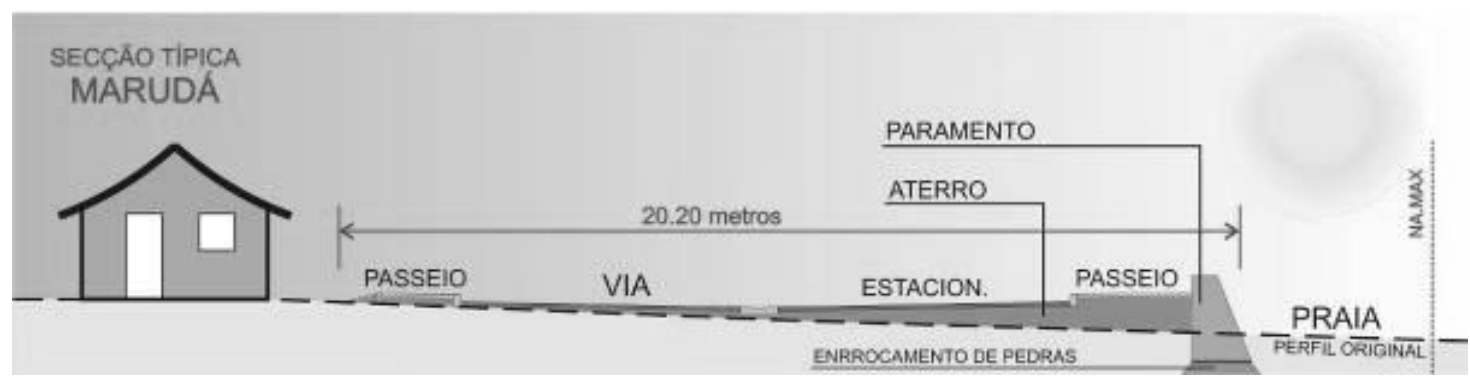

Figura 21 - Secção típica do aterro do sistema viário retirada do projeto urbanístico de Marudá

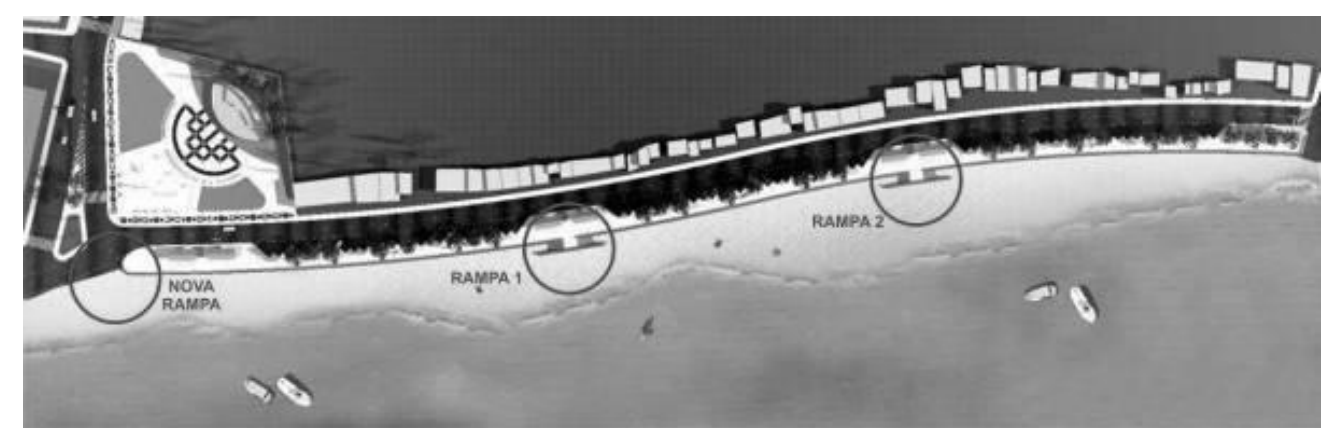

Figura 22 - Vista geral do projeto - sistema viário e muro de contenção paralelos à linha dos lotes posicionamento das rampas 1 e 2 e da nova rampa, construída posteriormente, em Marudá, julho de 2006 
É importante observar o perfil longitudinal da praia de Marudá. Na porção oeste, nos pontos próximos à Nova Rampa e à Rampa 1, a praia apresenta maiores tendências à perda de sedimento. Nesses pontos, a areia sob as bases das duas rampas está sendo retirada, deixando suas fundações aparentes, enquanto a porção mais a leste apresenta tendências de deposição de sedimentos, principalmente devido à atividade eólica. A Rampa 2 está sendo, aos poucos, coberta pela areia (Figuras 23 e 24).
Devido à perda de sedimento, as fundações do muro já estão aparentes, principalmente nas rampas, apresentando algumas rachaduras e vãos sob o paramento. Esse tipo de patologia pode significar futuros problemas para a estrutura. Foram colocadas pedras na base do muro, longitudinalmente, com o objetivo de dissipar a energia e conter os efeitos nocivos das ondas (Figuras 25 e 26).

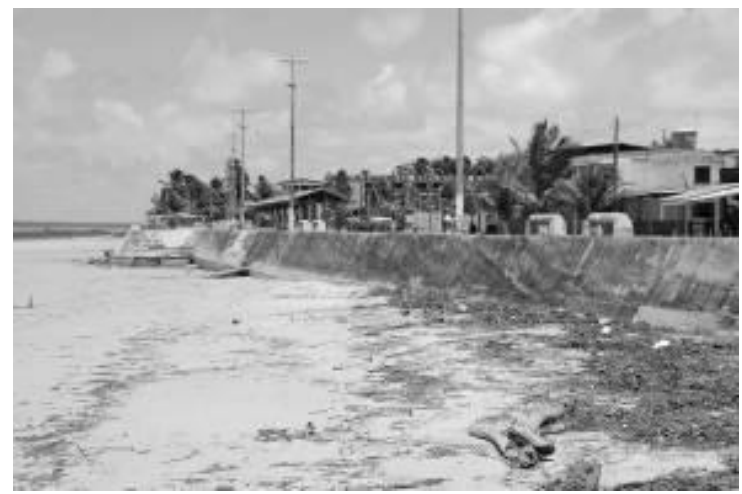

Figura 23 - Rampa 1 apresentando solapamento e acentuado desnível próximo a sua base, em Marudá, maio de 2009

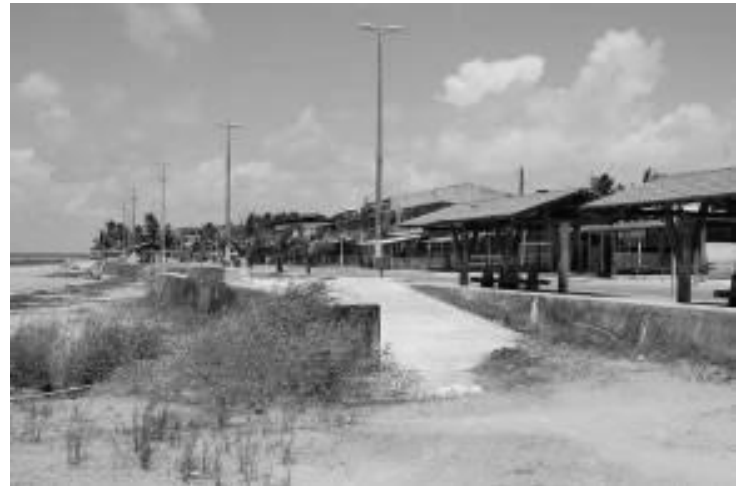

Figura 24 - Deposição de sedimentos à base da Rampa 2 devido à ação eólica, em Marudá, maio de 2009

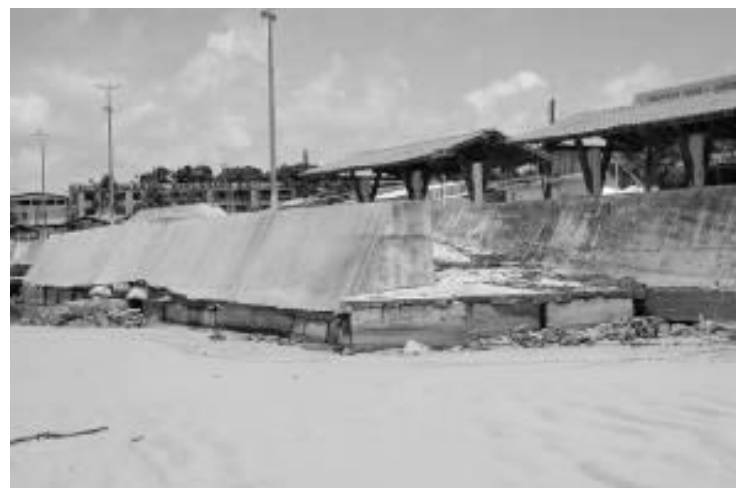

Figura 25 - Base da Rampa 1 apresentando solapamento em sua base com suas fundações aparentes aparecimento de vãos na estrutura, em Marudá, maio de 2009 


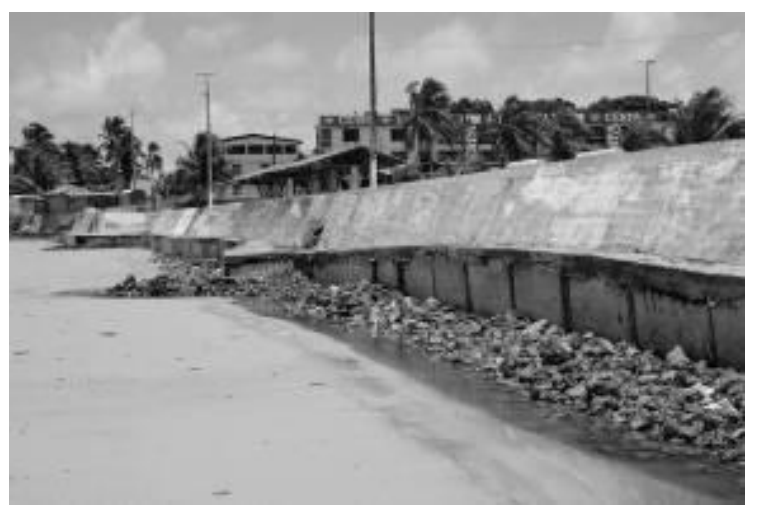

Figura 26 - Tentativa de contenção do solapamento da base do muro com pedras, em Marudá, maio de 2009

No caso de Marudá, os lotes e edificações já estavam consolidados sobre a berma praial. Se se analisar apenas o aspecto técnico, relacionado à manutenção do perfil praial, o ideal seria a remoção dessas edificações de cima do perfil. Porém isso não foi considerado, sobretudo devido aos valores a serem pagos aos moradores em indenizações.

Sendo assim, o Estado decidiu manter as edificações no local consolidado e construir o sistema viário e o muro de contenção entre os lotes e a linha de preamar como forma de conter o avanço da ocupação sobre a água e reprimir novas ocupações na praia. Porém, isso significa edificar ainda mais sobre o perfil da praia, o que tecnicamente não é recomendável. Contudo, na prática, é a solução mais viável para atingir os objetivos estabelecidos e conter a degradação do local.

Portanto, o posicionamento do muro em Marudá, e em grande parte dos casos, é a resultante entre o espaço necessário para o sistema viário (vias, calçadas, equipamentos, etc.) e a linha de preamar.

Segundo Cativo (2009) ${ }^{10}$, a estrutura projetada não previa trabalhar com a ação direta da água e, após constatada a irreversibilidade do posicionamento, foi sugerida a solução de enchimento de pedras dentro do corpo da rampa para garantir sua estabilidade. Por questões de economia, a solução não foi executada; e no ponto de encontro entre a rampa e o muro, a ação da água provocou o solapamento da areia sob o paramento e o consequente afundamento da estrutura (Figuras 27 e 28). O problema de desmoronamento ocorreu na Rampa 1, embora tenham sido constatados, atualmente, problemas de perda de sedimentos na base da Nova Rampa e da Rampa 1, as duas

${ }^{10}$ Informação verbal em entrevista concedida em 10 de março de 2009, por Edenilton Pantoja Cativo. estruturas mais próximas da linha de maré alta, que sofrem mais com a ação da energia das ondas.

\section{Intervenção na praia do Amor, Outeiro, RMB}

O Distrito de Outeiro é uma localidade balneária situada na Ilha de Caratateua (conhecida como Outeiro), próxima ao Distrito de Icoaraci, todos pertencentes ao Município de Belém. Suas praias de água doce são banhadas pela Baía do Guajará, e a proximidade a Belém (18 $\mathrm{km}$ por rodovia) juntamente com a facilidade de seus acessos, fazem com que essas praias sejam bastante procuradas em fins de semana, feriados e férias.

O caso aqui descrito está localizado na Praia do Amor, uma das praias da Ilha de Caratateua, apresenta cerca de $1 \mathrm{~km}$ de extensão e, aproximadamente, $220 \mathrm{~m}$ de zona de intermaré com presença de berma praial, cristas e calhas. Porém, este estudo é desenvolvido sobre uma porção de aproximadamente $350 \mathrm{~m}$, correspondente à área objeto de um projeto urbanístico contratado pelo Governo do Estado do Pará, executado pela Prefeitura Municipal de Belém, para proporcionar melhorias infraestruturais à localidade.

O Governo do Estado do Pará firmou contrato cujo objeto era a elaboração de Projetos Executivos de Urbanização para um trecho da Praia do Amor, em Outeiro, com o objetivo de promover melhorias urbanas, resguardar o espaço público para uso coletivo e, sobretudo, proporcionar à população lazer mais seguro e salubre.

Essa intervenção surgiu da análise da então configuração física e funcional do local, a qual apontou, como solução para a maioria dos problemas identificados, a construção da infraestrutura de circulação da orla. A intervenção foi planejada para interferir o mínimo possível na paisagem natural, sem modificar o uso e o funcionamento há anos consolidados no local. 


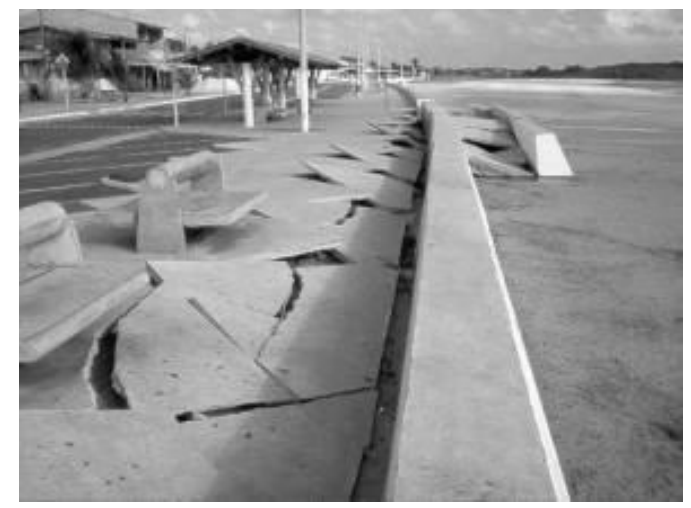

Figura 27 - Calçada afetada pelo colapso do paramento, em Marudá, julho de 2004

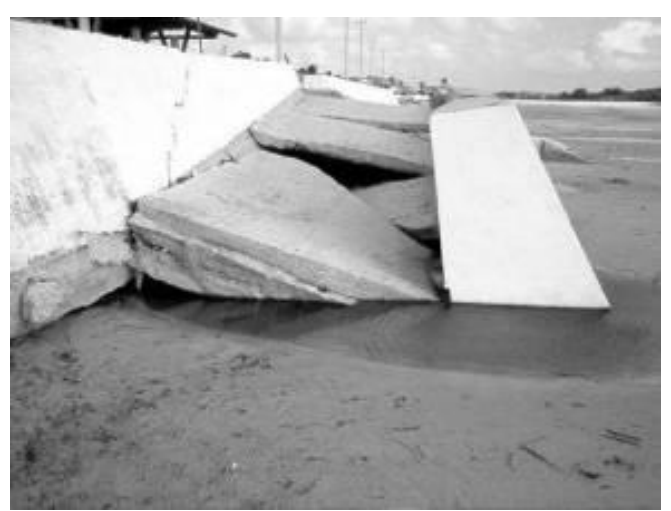

Figura 28 - Rampa 1 destruída - acúmulo de água denunciando o solapamento em sua base, em Marudá, julho de 2004

Assim, foi projetada uma via litorânea, paralela à praia, ligando as extremidades das Alamedas Enock Pinto e João Amanajás. Adjacente à via, concebeu-se um sistema de passeios e canteiros, destinados à circulação de pedestres, ao lazer e, sobretudo, ao apoio à prestação dos serviços de alimentação ali consolidados (Figura 29).

A sinuosidade do traçado proposto, além de ser pertinente para intervenções nas quais se pretende suavizar o impacto da urbanização de áreas naturais, deveu-se, sobretudo, à intenção de sacrificar o menor número possível de árvores.

$\mathrm{O}$ projeto foi concebido para ordenar física e funcionalmente o lugar. Acredita-se que a consolidação de uma via litorânea formalizada para estruturar a circulação de veículos organiza de forma segregada os fluxos de acordo com suas naturezas, dando segurança, assim, aos pedestres. Ficam claros, ainda, com a definição do alinhamento do sistema viário, os limites entre as propriedades públicas e as privadas, de forma que se tenha livre acesso nas áreas coletivas e se proteja a privacidade dos lotes particulares.

Outro limite formal estabelecido pelo projeto é a divisa entre a praia e a área urbanizada. Essa fronteira é marcada por um muro de contenção que, erigido no local, também faz a contenção do aterro sobre o qual o sistema viário foi construído, e também evita alagamentos em épocas de grandes marés.

O muro de contenção foi proposto e executado em concreto ciclópico, já que essa solução, além de ter sido eleita como a mais adequada estruturalmente para a situação, é, também, econômica, pois apresenta boa exequibilidade e se utiliza de materiais facilmente encontrados na região. O paramento tem funções múltiplas no conjunto, servindo de contenção para o material de base e sub-base do sistema viário, e como elemento de proteção contra eventuais inundações da área urbanizada.

A existência do muro de arrimo não dificultará o trânsito entre o passeio e a praia, uma vez que os acessos à faixa de areia são feitos por meio de treze escadas e duas rampas que fazem parte do conjunto do muro, distantes entre si $20 \mathrm{~m}$ aproximadamente. As rampas foram projetadas para permitir acessibilidade aos portadores de necessidades especiais ou pedestres com dificuldade de locomoção (Figura 30). 


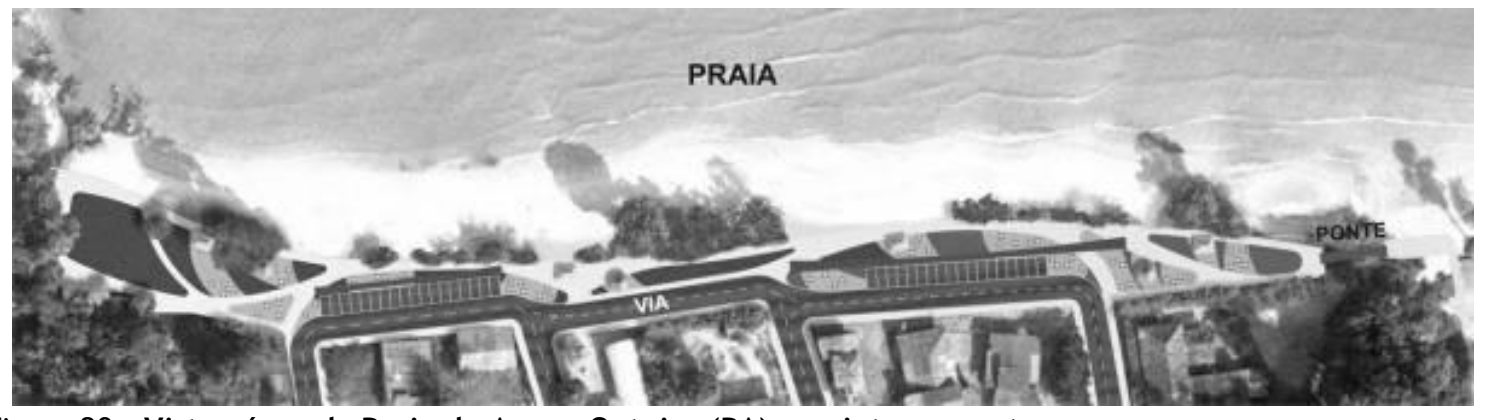

Figura 29 - Vista aérea da Praia do Amor, Outeiro (PA): projeto proposto

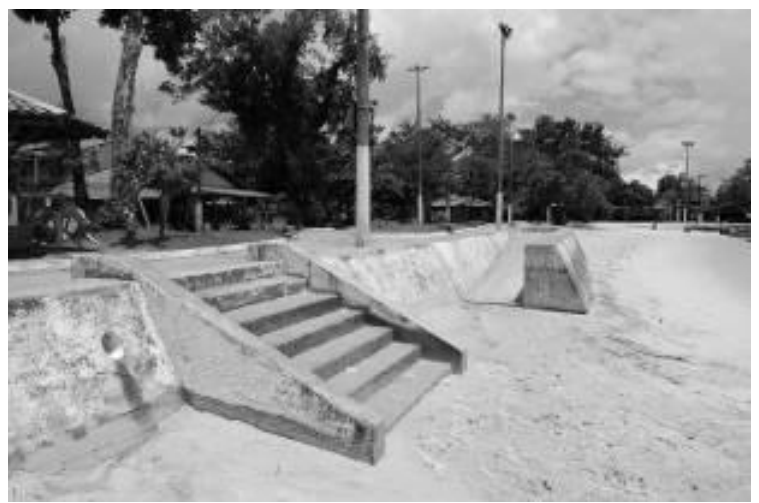

Figura 30 - Sistema de escadas e rampas de acesso à praia, na Praia do Amor, Outeiro (PA), maio de 2009

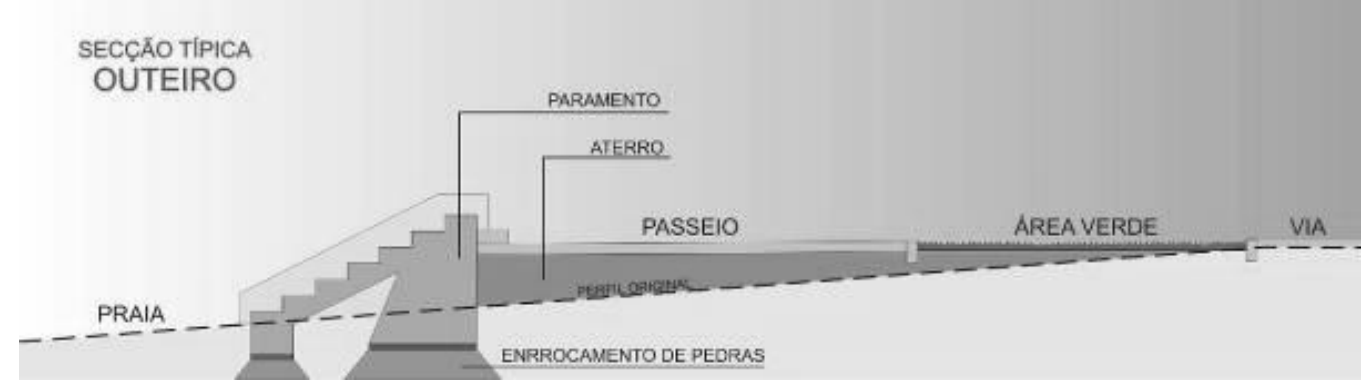

Figura 31 - Secção típica de Outeiro (PA) - paramento trapezoidal fazendo a contenção do aterro do sistema viário

A solução de muro de peso de perfil trapezoidal, adotada nesse caso, foi possível em razão dos bons resultados obtidos na análise dos materiais, resultante das sondagens executadas ao longo da diretriz de posicionamento do muro componente do projeto em questão (Figura 31).

A posição do muro de contenção foi definida como ponto de partida para as demais ações projetuais, contemplando as necessidades técnicas da obra, procurando impactar negativamente o mínimo possível no ambiente e na vida dos que ali residem ou visitam. A área já estava ocupada anteriormente ao projeto, o que reduziu as possibilidades de posicionamento do muro. Portanto, o muro foi posicionado entre os lotes e a linha de preamar sobre o perfil da praia apontada pelo levantamento topográfico feito à época pela equipe do projeto.

Muitos casos de obras costeiras são instigados por danos causados pela força da água sobre os patrimônios edificados. Ou seja, o sistema marinho nem sempre é o foco principal dessas intervenções. De um lado é necessário proteger das ações antrópicas o ambiente marinho, suas especificidades regionais e seus sistemas. Por outro lado, engenheiros e urbanistas se deparam com problemas de erosão e inundações, que normalmente provocam perdas materiais e humanas, a serem sanados.

A solução dada para esse tipo de situação, geralmente, é construir um muro de contenção e posicioná-lo após o perfil praial, a determinada 
distância da linha de preamar, de forma a proteger as edificações da ação direta da água. Assim foi executado no caso da Praia do Amor, porém com o agravante de as edificações já se encontrarem estabelecidas sobre o perfil, avançando o sistema viário e, consequentemente, o muro de contenção sobre a praia, o que, sob o aspecto técnico, não é recomendado.

Por isso, e agravado pela solução inadequada na ancoragem da escada ao paramento, constataramse algumas rupturas e desmoronamentos em algumas das escadas da porção oeste do muro (Figuras 32 e 33). As edificações ficarão protegidas por determinado período, enquanto o nível da água não elevar e ultrapassar o coroamento do muro, ou mesmo quando a força e amplitude das marés provocarem o colapso da estrutura.

Em levantamentos fotográficos feitos em abril de 2009, observou-se a leste da Praia do Amor um perfil mais depositivo, com acúmulo de sedimentos à base do muro construído. Esse acúmulo se dá principalmente devido à ação eólica, uma vez que a maré não atinge com frequência essa parte da praia, enquanto na porção oeste, que sofre mais com a ação da maré, o perfil demonstra características mais erosivas, denunciadas pelas quedas das escadas. Portanto, o posicionamento incorreto do paramento com relação à ação da água pode influenciar na vida útil da estrutura (Figuras 34 e 35).

As situações descritas acima deixam claro que o posicionamento do muro de contenção é muito importante para o funcionamento a que se propõe essa estrutura. Esse tipo de cuidado pode evitar, de forma efetiva, problemas com erosão e inundações, resguardar as edificações e atividades sociais e econômicas resultantes das ações antrópicas, além de proteger o perfil praial e o ambiente costeiro das mudanças nocivas que a proximidade com as obras pode ocasionar.

Foto: Lima (2009).

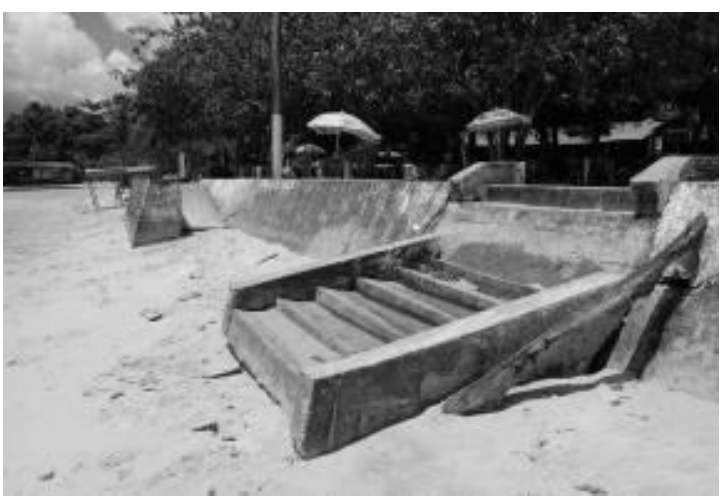

Figura 32 - Uma das escadas desmoronadas na Praia do Amor, Outeiro (PA), maio de 2009

Foto: Lima (2009).

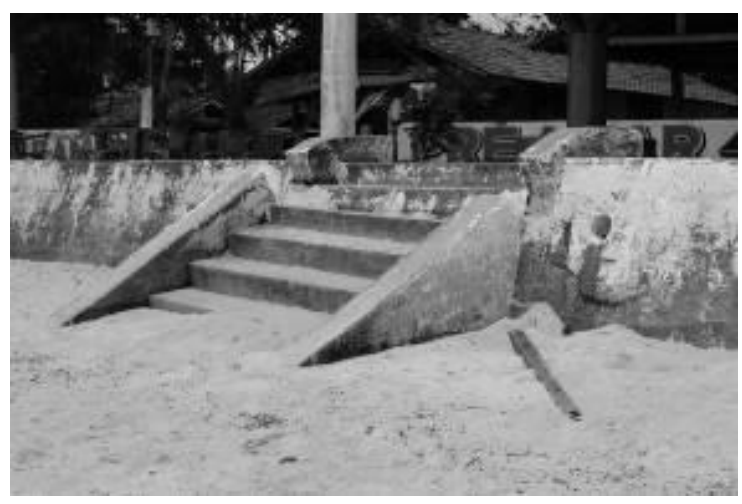

Figura 33 - Escada desmoronada na Praia do Amor, Outeiro (PA), maio de 2009 


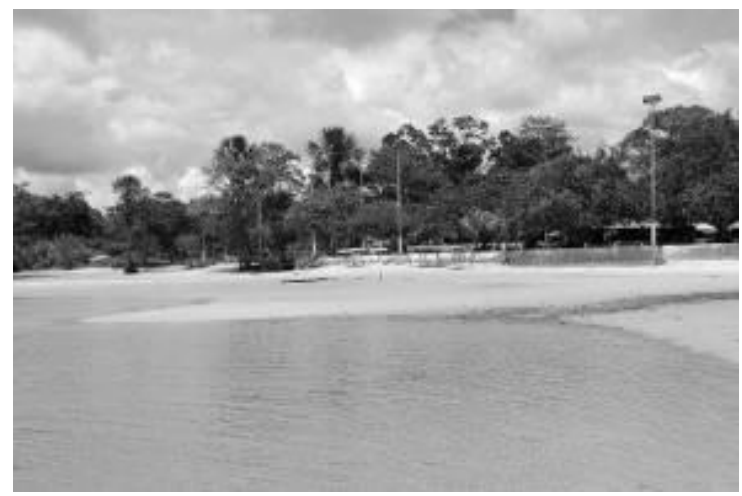

Foto: Lima (2009)

Figura 34 - Lado oeste com maior proximidade com a maré: perfil erosivo, queda das escadas, na Praia do Amor, Outeiro (PA), maio de 2009

Foto: Lima (2009).

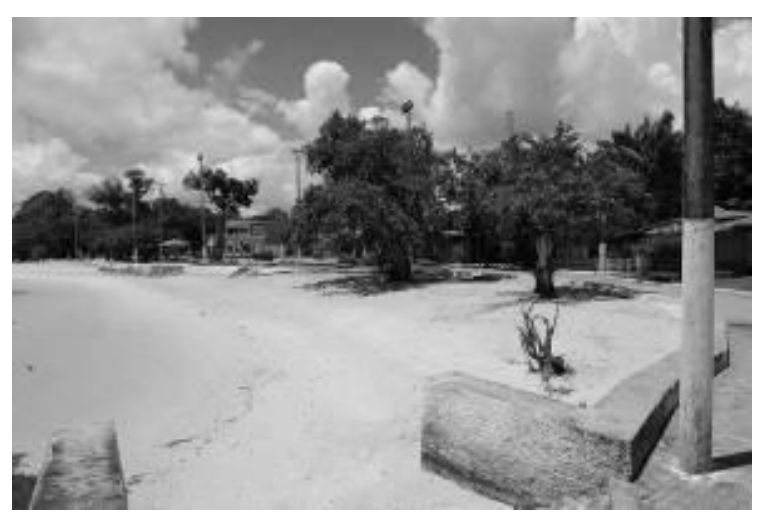

Figura 35 - Lado leste com Menor influência de ondas: depósito de sedimentos à base do muro devido à ação eólica, na Praia do Amor, Outeiro (PA), maio de 2009

\section{Conclusões e diretrizes}

Para que as decisões projetuais quanto ao posicionamento do muro de contenção em praias, na qualidade de limite da urbanização, sejam coerentes e eficazes para os envolvidos no ambiente, recomendam-se as diretrizes aqui relacionadas. Tais diretrizes são construídas com a ratificação dos resultados dos casos estudados:

(a) delimitar a área exata da intervenção, estabelecendo claramente seus limites por meio de levantamentos cadastrais, planialtimétricos e fotográficos. Em ambos os casos aqui apresentados, foram feitos os levantamentos planialtimétrico do terreno e cadastral dos lotes e árvores, além da linha de preamar aproximada. Cabe ressaltar que, apesar de esse nível máximo da água variar durante o ano em função da dinâmica costeira, foi o que orientou os projetos de intervenção quanto ao posicionamento do muro de contenção;

(b) levantar as demandas sociais, econômicas e infraestruturais para definir precisamente que tipo de obra será realizado. Nos casos em estudo, moradores e trabalhadores locais foram entrevistados a fim de elencar as demandas socioeconômicas e infraestruturais que poderiam influenciar positiva ou negativamente no projeto urbanístico proposto, embora essa coleta de informações não tenha sido sistematizada por nenhum método científico;

(c) fazer estudos climatológicos, hidrológicos e oceanográficos, coordenados por profissionais da área, a fim de levantar o histórico do ambiente praial. Não houve auxílio de profissional especialista para a realização dos estudos citados nas obras relacionadas. Apenas a linha de preamar determinada no levantamento topográfico foi levada em consideração, e estudos mais detalhados sobre a maré não foram executados;

(d) procurar posicionar o muro de contenção, determinando a área de proteção de $100 \mathrm{~m}$ a $50 \mathrm{~m}$, sugerida por Muehe (2004), para resguardar as estruturas de processos erosivos. A locação do muro de arrimo, geralmente, é a resultante entre o espaço necessário para o sistema viário (vias, calçadas, equipamentos, etc.) e a linha de preamar. Nas praias de Marudá e do Amor não foi diferente: o posicionamento do muro em questão seguiu o 
mesmo critério, o que inviabilizou a manutenção de uma área de proteção;

(e) em casos nos quais não seja possível manter a zona de proteção estabelecida para as novas construções, tentar posicionar o muro após o término do perfil praial determinado previamente pelo profissional da área em seus estudos do perfil. Nos casos apresentados, não foi possível livrar o perfil praial da construção do muro de contenção, uma vez que ele foi locado de acordo com a necessidade do sistema viário, porém se preocupando em acompanhar a linha de preamar determinada pelo levantamento topográfico para reduzir os esforços da maré sobre o paramento de concreto; e

(f) m situações em que o perfil já esteja ocupado por edificações e que não sejam passíveis de remanejamento, calcular o paramento de forma a suportar a ação das ondas e correntes para evitar colapsos estruturais e danos materiais e humanos na área. Esse é o caso das duas situações aqui descritas. O paramento foi posicionado dentro do perfil praial. Com o movimento da maré, a água atinge frequentemente as estruturas proeminentes das escadas, que entraram em colapso.

Por fim, a pesquisa aponta para a necessidade de que os profissionais responsáveis por fazer projetos urbanísticos em áreas de orlas, que, em muitos casos, pouco conhecem o dinamismo do ambiente praial e a complexidade do sistema marinho que envolve tais áreas, realizem levantamentos em conjunto com oceanógrafos, geólogos marinhos, engenheiros hidráulicos, geógrafos e geomorfólogos para um aprofundamento da aplicação dos levantamentos necessários do sistema praial em seus projetos. $\mathrm{O}$ tempo investido para executar tal tarefa é de suma importância, e quanto maior for o período de levantamentos periódicos dos parâmetros oceanográficos, hidrológicos e climatológicos, mais preciso será o diagnóstico da área.

\section{Referências}

ALVES, M. A. M. S. Morfodinâmica e Sedimentologia da Praia de Ajuruteua-NE do Pará. 104 f. 2001. Pará. Dissertação (Mestrado em Geologia e Geoquímica) - Centro de Geociências, Universidade Federal do Pará, Belém, 2001.
BRASIL. MINISTÉRIO DO MEIO AMBIENTE; MINISTÉRIO DO PLANEJAMENTO, ORÇAMENTO E GESTÃO. Projeto Orla: subsídios para um projeto de gestão. Brasília: MMA; MPO, 2004. Disponível em: <http://www.mma.gov.br/estruturas/orla/_arquivos /11_04122008110506.pdf >. Acesso em: 13 jan. 2009.

BRASIL. MINISTÉRIO DO MEIO AMBIENTE; MINISTÉRIO DO PLANEJAMENTO, ORÇAMENTO E GESTÃO. Projeto Orla: fundamentos para gestão integrada. Brasília: MMA, 2006. Disponível em: <http://www.mma.gov.br/estruturas/orla/_arquivos /11_04122008111238.pdf >. Acesso em: 13 jan. 2009.

CICIN-SAIN, B; KNECHT, R. W. Integrated Coastal and Ocean Management: concepts and practices. Washington: Island Press, 1998.

FARIAS, Daniel Ramôa. Variabilidade MorfoSedimentar das Praias Estuarinas do Amor e dos Artistas (Ilha de Caratateua. Pará). 2006. 141 f. Dissertação (Mestrado em Geologia e Geoquímica) - Centro de Geociências da Universidade Federal do Pará, Belém, 2006.

FARINACCIO, Alessandro. Impactos na Dinâmica Costeira Decorrentes das Intervenções em Praias Arenosas e Canais Estuarinos de Áreas Densamente Ocupadas no Litoral de São Paulo: uma aplicação do conhecimento a áreas não ocupadas. 2008. $218 \mathrm{f}$. Tese (Doutorado em Oceanografia Química e Geológica) - Instituto Oceanográfico da Universidade de São Paulo, São Paulo, 2008.

FISCHER, Andrea. Morfodinâmica do "Saco do Laranjal": costa noroeste do estuário laguna dos patos. 2005. Dissertação (Mestrado em Engenharia Oceânica) - Escola de Engenharia Oceânica, Universidade Federal do Rio Grande do Sul, Porto Alegre, 2005.

FREITAS, Luiz Fernando. Muro em Sacos de Solo Cimento. 2009. 1 Fotografia. Color. 15 x 12 $\mathrm{cm}$.

LIMA, Diogo. Escadas desmoronadas da Praia do Amor, Outeiro (Pará). 2009. 2 Fotos. Color. 15 x $12 \mathrm{~cm}$.

MUEHE, D. Estado Morfodinâmico Praial no Instante da Observação: uma alternativa de identificação. Revista Brasileira de

Oceanografia, v. 46, n. 2, p. 157-169, 1998. 
MUEHE, D. Definição de Limites e Tipologias Morfodinâmico e Evolutivo. In: BRASIL. MINISTÉRIO DO MEIO AMBIENTE. Projeto Orla: subsídios para um projeto de gestão. Brasília: MMA, 2004.

SABAINI, Renata Stelzer. Morfodinâmica Praial: segurança ao banho e perfil do banhista da praia de Camburi, Vitória/ES. 72 f. 2005.

Monografia (Trabalho de Conclusão de Curso em Oceanografia) - Centro de Ciências Humanas e Naturais, Universidade Federal do Espírito Santo, Vitória, 2005.
SOUZA, Marco Antônio de Lyra. Benefícios Ambientais no Controle de Erosão Costeira com o Uso do Dissipador de Energia "Bagwall" no Litoral de Alagoas. Revista da Gestão Costeira Integrada, Maceió, v. 8, n. 2, p. 139-148, 2008.

UNIVERSIDADE DO ESTADO DO RIO DE JANEIRO. Faculdade de Engenharia. Departamento de Estruturas e Fundações. Estruturas de Contenção de Muros de Arrimo. 2009. Disponível em: <http: <www.eng.uerj.br/ denise/pdf/muros.pdf>. Acesso em: 17 mar. 2009. 